\title{
TOPONYMY OF THE ANCIENT SARY-ARKA (NORTH-EASTERN KAZAKHSTAN)
}

\author{
Kuat Saparovi ${ }^{1}$ Jiri Chlachula ${ }^{2,3}$, Aigul Yeginbayeva ${ }^{1}$ \\ ${ }^{1}$ Department of Physical Geography, L.N. Gumilyov Eurasian National University, Astana, Kazakhstan \\ ${ }^{2}$ Institute of Geoecology and Geoinformation, Adam Mickiewicz University in Poznań, Poland \\ ${ }^{3}$ Laboratory for Palaeoecology, Tomas Bata University in Zlín, Czech Republic
}

Manuscript received: February 21, 2018

Revised version: May 31, 2018

Saparov K., Chlachla J., Yeginbayeva A., 2018. Toponymy of the Ancient Sary-Arka (North-Eastern Kazakhstan). Quaestiones Geographicae 37(3), Bogucki Wydawnictwo Naukowe, Poznań, pp. 35-52. 7 figs.

ABSTRACT This study examines the etymology of the principal physiographic entities of the ancient Sary-Arka areameaning in the old Turkic language Yellowing Ridge - encompassing the present territory of parkland-steppes, rocky highlands and the adjacent mountains of North and East Kazakhstan. The current linguistic evidence points to a complex and chronologically long culture-historical development reflected by the local place names best-recorded for the major rivers and mountains (hydronyms and oronyms, respectively). Not all geo-site names are securely determined by using modern onomastics. Records of material culture provide additional multi-proxy information. Local uniformity of some toponyms across the extensive area assuming a common cultural background attests to a broader ethnic homogeneity and/or mobility of the ancient populations inhabiting this vast and geomorphically mosaic land. This suggests a close relationship and interactions (including demographic exchanges and mixing) between the past pastoral ethics in the parkland-steppe and semi-desert areas north of Lake Balkhash between the Aral Sea and the southern Urals in the West and the Alatau-Altai Mountain systems in the East. Whereas the hydronyms of the Sary-Arka may have a rather complex and not fully clear origin with a connection to the Turkic-Tatar medieval tribes and nations' occupancy in northern Central Asia eventually modified into the present Kazakh language forms, the oronyms of the East Kazakhstan mountain ranges indicate the Mongolian roots.

KEY WORDS: toponymy, ethnic history, cultural history, Sary-Arka, East Kazakhstan

Corresponding author: Jiri Chlachula, Altay@seznam.cz

\section{Introduction}

The onomastics place name (eponymy) research has a long tradition in Kazakhstan (Slovtsov 1844, Groznyi 1940, Medoyev 1948, Bayandin 1949, Tatischev 1950, Konkashpayev 1959, Margulan et al. 1966, Popova 1966) in respect to the historical imprint to landscape left by ancient populations (Plit and Myga-Piątek 2014). A linguistic study focus in relation to the country's geography has been on understanding a regional toponymy of the present Kazakh parkland-steppes and some particular places associated with a sequenced culture-historical occupation of these lands by prehistoric and early historical nomadic ethnics. This paper examines the etymology of the principal geographical entities - the specific landscape forms - of the present North and East Kazakhstan - the historical area with a poetical name Sary-Arka/Saryarka. This term is known since the ancient times, meaning in the old Turkish language Yellowing Ridge (Margulan et al. 1966). Yet, its linguistic roots may go far back into the prehistoric (Bronze 
Age) Mesopotamia and the Sumerian civilization (Postgate 1993). According to present archaeology and ethnology evidence Sary-Arka has an actual geomorphological foundation and a direct linkage to the mosaic relief of the dry undulating rocky steppes and parklands of the northern Central Asia. In the ancient lyrics, this vast and open landscape of early nomads was venerated and glorified by the Bronze Age Akyn nation. It is also mentioned in the ancient Kyrgyz epics (Van der Heide 2015). Some large rivers with their tributaries flow through this extensive area that played the principal historical role in the cultural evolution and the socio-economic development and life of early semi-sedentary populations settling this territory.

Rich prehistoric and early historical cultural monuments and archaeological localities are found in diverse topographic settings across Sary-Arka bearing witness of a chronologically long and ethnically divergent inhabitation of this part of Central Asia by hunter-gatherer and subsequent pastoral and early agricultural communities (Khazanov 1984, Frachetti 2006. Outram et al. 2009). A close linkage of these sites with the most prominent and strategic topographic settings since the Palaeolithic times is evident, pointing to adaptation to the mountain and steppe environments (e.g., Levine and Kislenko 1997, Vishnyatsky 1999, Zakh et al. 2010, Chlachula 2010, 2017, Kotov 2016). The mountain regions of Central Asia are believed to facilitate spread of early agriculture since the Bronze Age (Motuzaite Matuzeviciute et al. 2015). The most famous archaeological sites of the Sary-Arka and the adjacent Southern Altai are associated with the Iron-Age Scythian civilization with traces of settlement in the steppes, river valleys as well as on the alpine Altai plateaus with the Worldfamous burial mounds (kurgan) sealed in permafrost grounds (Bourgeois et al. 2000, Polosmak 2001, Samashev 2001, 2011, Gorbunov et al. 2005, Chlachula 2018).

This study discusses toponymy of the main regional hydronyms and oronymes (place names of the principal rivers and mountains, respectively) found on the territory of northern and eastern Kazakhstan that still do not have a uniform and generally accepted interpretation. Linguistic, historical and geographical studies and their conclusions are taken into account summarizing the current knowledge and scientific hypotheses based on the historical and geographical literature analysis. This also concerns the etymology of the regionally principal place names of the main rivers and lakes such as Yertys and Zaysan, and the mountains ranges of the Altai, Tarbagatai, Bayanaul and some other (Yegorina 2002). According to the present evidence, there is no common and scientifically grounded lexical clarification of these geomorphic entities. This may be explained by the 150-year presence of the Mongolian Oyrats in the NE Kazakhstan during the $17^{\text {th }}$ and the first half of the $18^{\text {th }}$ centuries, and the previous Tatar and Mongol invasions to the territory of Sary-Arka during the $13^{\text {th }}$ century that modified or completely obliterated the former place names and their original meanings used by the indigenous tribes. There are some exceptions, such as the hydronym of Irtysh, referring to the main river flowing through the Eastern and NE Kazakhstan that clearly derives from the river Yertys encountered in the ancient Turkish written records. The Yertys etymology is also found in the early Hungarian annals and chronicles describing the nation's prehistory and early historical times. The original linguistic assignment Irciss, however, probably relates to the Ket nation from whom this name was taken over by the medieval Mongols. Finally, examples of physiogeography peculiarities and specific geo-forms of the north-central and eastern Kazakhstan are presented in linkage with the regional historical toponymy. Apart of clarification of the place names' origin, study of the prehistoric and historical landscape change has relevance for mapping of the present geo-relief structures, for understanding of their perception by the former nomads as well as promotion of the modern geo-tourism in the Republic of Kazakhstan (Goessling et al. 2005, Yegorina et al. 2016, Geta et al. 2015, Mazbaev 2016, Saparov and Zhensikbayeva 2016, Zhensikbaeva et al. 2017, 2018).

\section{Study Area: Geography and Geological History}

The north-central and eastern Kazakhstan Sary-Arka - is naturally a very diverse area with a high degree of geo-diversity characterized by deep ravines, erosional tectonic platforms and 


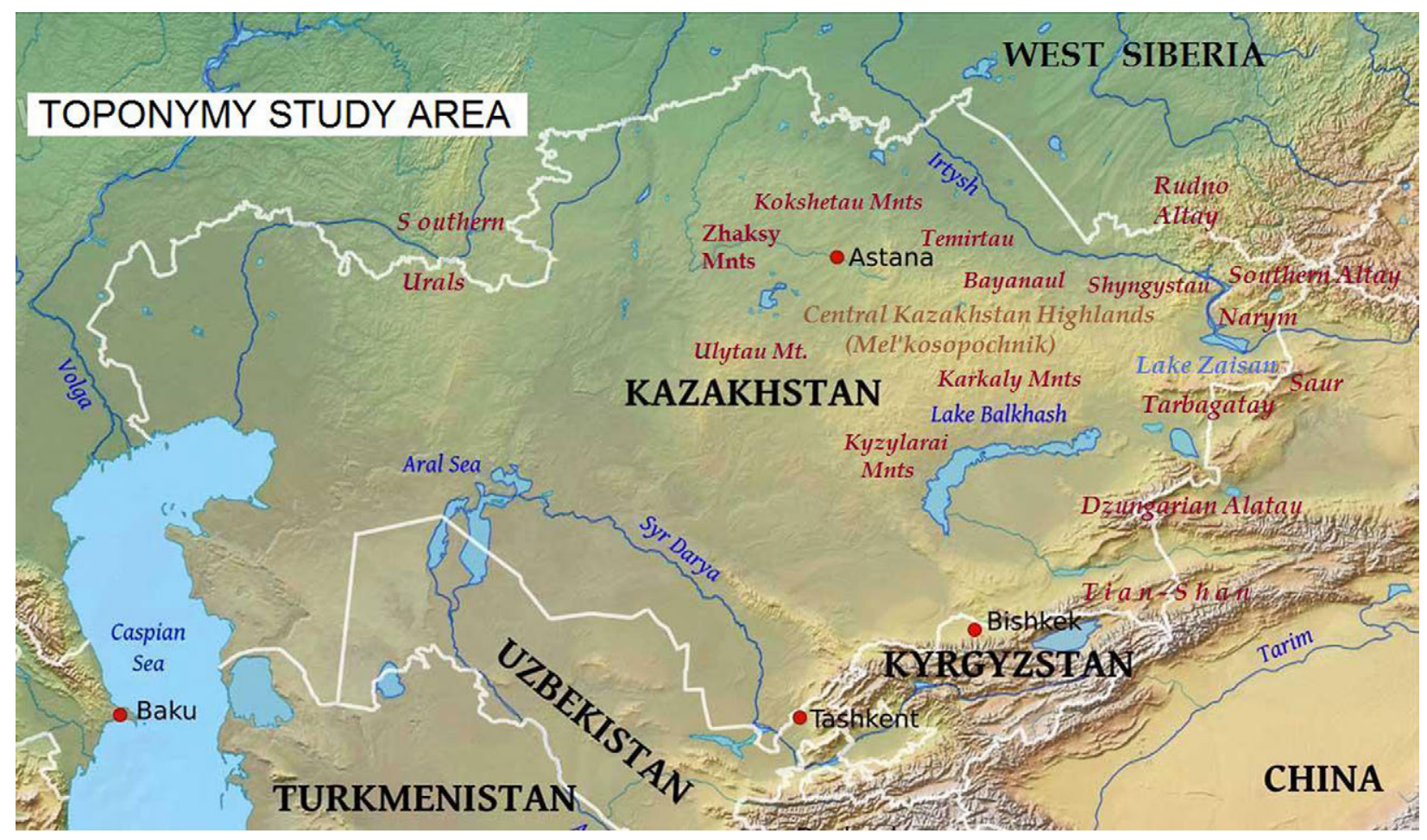

Fig. 1. Geographic location of the study area with the oronyms and hydronyms of northern and eastern Kazakhstan (the territory of Sary-Arka) discussed in the text.

rocky hills surrounded by open parkland-steppes. It is rich of natural, especially metallic minerals that were explored and exploited for since the prehistoric times (Samashev 2001, Kungurov 2006, Baumer 2016a-c). The dominant semi-arid steppe area is covered by feather grasses (Poaceae - Stipa sp.), reminding a fox tail, broadly distributed across the country (Nobis and Gudkova 2016) and indicative of dry continental steppes with hot summers and windy frosty winters with a little snow cover. The historical name Sary-Arka refers to the vast geographical area bound from the South by the Aral-Balkhash Lowland, in the North by the West Siberian Lowland, in the West by the Caspian Plain and the Torgai Valley, and in the East by the Irtysh River valley (Fig. 1). It has most likely a geomorphologic connotation to the prevalent relief of North-Central Kazakhstan (Medoyev1948, Margulan et al. 1966). From the modern geographic and geomorphic point of view, the Sary-Arka includes a series of low-elevation yellowish granite ranges and mountain ridges (Kokshetau, Karkaraly, Baitau/Bayantau, Shyngystau, Ulytau, Atasu, Imantau, Kyzylzhar, Munly, Mugodzhary, Zhaksy, Zhangystau and some other) drained by small rivers and streams in-charging into the Aral-Balkhash basin in the southern part of the territory. Some larger rivers drain the area in the north (Yesil, Tobol) belonging to the Irtysh/Yertys basin.

Biogeographically, the study area encompasses the present parklands, steppes and semi-deserts of East Kazakhstan (Fig. 2). These are aligned by the chain of mountains from the North-West (the Southern Urals), the North-East (the Altai) and the South-East (the Tarbagatay Range). The central part is shaped by low-elevation hills (the Central Kazakh Highlands) adjoining the Zaisan Depression in the East filled by lakes - the Zaisan and the Bukhtarma Basins (300-400 m a.s.l.) amid of a dry xerotheric landscape. The Southern Altai is the principal mountain system of East Kazakhstan with elevations $>4,000 \mathrm{~m}$ a.s.l., bordering in the East the Mongolian Altai through the TabonBogdo-Ula massive (Nairamdal Mt., 4,356 m a.s.l.) (Chupakhin 1968). The East Kazakshtan orogenic massive is divided into several E-W oriented montane formations (Southern Altai, Sarymsakty, Narym and Kurchum) connecting through the Tarbagatai Range (2,992 $\mathrm{m}$ a.s.l.) and the Dzhundarskiy Alatau $(4,464 \mathrm{~m}$ a.s.l.) to the Tian-Shan Mountains (Schultz 1948, Mikhailov 1961). Geomorphologically, the alpine relief is 


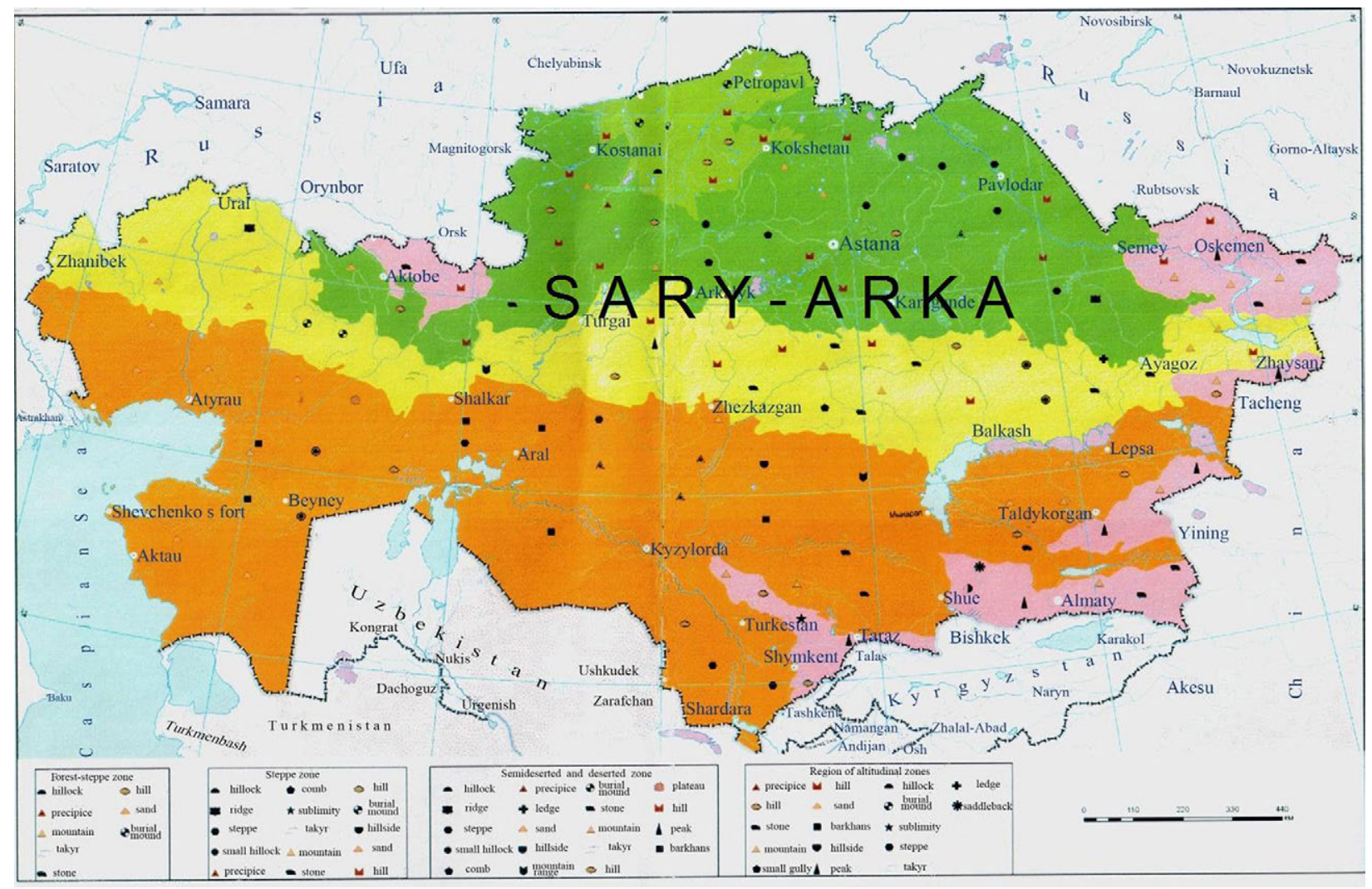

Fig. 2. A bio-geographic map of Kazakhstan with the specific vegetation-cover zones, including, from North to South: parklands (forest-steppes), steppes, semi-deserts/deserts and the mountain zone in the NW and eastern part of the territory. Displayed are some specific geo-sites (legend).

characterized by steep erosional northern slopes representing uplifted relics of old plateaus $(>3,000 \mathrm{~m}$ a.s.l.) with a westwards-decreasing topographic gradient (3,900-2,300 $\mathrm{m}$ a.s.l.). The enclosing inter-basin generated by rifting during the Hercynian orogenesis is largely filled by Paleozoic, Devonian and Carboniferous sea deposits (Deviatkin 1965, 1981, Erofeev 1969, Mikhailova 2002). The central steppe area is built by weathered Proterozoic granites in places interspersed by gneiss units exposed to the present surface in the form of rounded hills and up-to 100 m-elevated flat denudation platforms. These stretch across the land as parallel-running fold erosional relics adjoining the rocky Melkosopochnik (highlands) of East-Central Kazakhstan (Svarichevskaya 1965).

The present-day relief of East Kazakhstan provides evidence of a complex landscape development triggered by past climate change and the regional tectonic activity (Nekhoroshev 1958, 1967, Dodonov 2002, Akhmetyev et al. 2005, Dyachkov et al. 2014). Three biogeographic provinces reach the present territory - the central Kazakhstan
(Aral Sea-West Siberian) province, the southern Siberian (Yenisei) province and the Central Asian (Tian-Shan - Mongolian Altai) mountain province, with the latter having experienced the most intensive Quaternary physiography evolution accompanied by intensive erosion processes (Velikovskaya 1946, Grigoriev 1950, Chupakhin 1968). The pre-Cenozoic landscape history of the continental areas of Central Asia is characterized by a low topographic gradient of old planation surfaces and former sedimentary sea basins subsequently broken by the late Miocene Earth crust movement (Nekhoroshev 1967). Neotectonic activity in conjunction with past global climate changes shaped the former relief particularly during at the Pliocene/Pleistocene and early Middle Pleistocene. The territorial Cenozoic (Late Pliocene-Middle Pleistocene) orogeny constructed a system of mountain ranges separated by deep depressions periodically filled by lacustrine water bodies (Dodin 1961). Intensive erosion of the uplifted geological formations led to several denudation cycles flattening the former relief (Aubekerov 1993). The topographic elevations 
are distorted by long-term weathering processes and sculptured into exposed vegetation-free rocky granitic hills of an average 700-750 $\mathrm{m}$ a.s.l. elevation (Obruchev 1951).

The progressive cooling during the late Middle and Late Pleistocene generated permafrost expansion on the northern and central plains merging with the insular mountain permafrost (Aubekerov and Gorbunov 1999). The glaciations in the mountain areas affected the adjacent ice-free foothills with prevailing continental cold and arid climate and intensified denudations processes (Kozhamkulova and Kostenko 1984). The regional geomorphology is largely defined by the Quaternary (palaeo-)landscape evolution with the warmer Early-Middle Pleistocene interglacials witnessed by strongly weathered palaeosols followed by increased continentality and a progressing relief gradient during the Late Pleistocene (Galakhov and Mukhametov 1999). A pronounced Last Glacial natural dynamics of the Altai Mountains is documented by spectacular glaciofluvial terraces in the principal mountain valleys associated with a release of deep icedammed glacial lakes subjected to cataclysmic drainages during the final stages of the regional alpine-zone deglaciation (Butvilovskiy 1985, Rudoy and Baker 1993, Rudoy and Kirianova 1994, Herget 2005). The Last Glacial (MIS 4 and 2) loess up to $20 \mathrm{~m}$ thick, interstratified by palaeosol, blankets the western mountain foothills and adjoining slopes in the main sedimentary (river) valleys (Chlachula 2010).

The present hydrology network belongs to the Irtysh drainage system with the Black Irtysh and Bukhtarma Rivers being the main tributaries. The modern climate is strongly continental, with warm semi-humid summers and very cold winters with an increasingly uneven precipitation distribution ranging from 1,500-2,000 mm/year on the NW Altai slopes to $200 \mathrm{~mm} /$ year in the Zaisan Lake basin with semi-desert vegetation transgressing into an open Kazakh steppe along the margins.

\section{Historical Research Background}

In consistency with the above geographic and geomorphic characteristics, the toponymy of Sary-Arka with its typical relief features and some unique geo-sites indicates a rather ancient origin. From a geo-environmental point of view, this may mirror presence of a variety of local ecosystems (Fig. 4) and culture-historical adaptation strategies of the past hunters' populations and later semi-sedentary nomadic communities settling this vast territory. The traditional understanding of the Sar-Arka is believed to mean Yellow watersheds or Outspread ridge (Medoyev 1948). In opposite, the etymology approach of this study, by referring to the old Turkish linguistic records, suggests an alternative interpretation - Sary - meaning A side, land of light and Arka meaning North. Thus, this place-name represents The Land of the North or The North Side. The eponymy roots, however, may go far back as to the Eneolithic $\left(5^{\text {th }}-4^{\text {th }}\right.$ Millennium BP) into the time of ancient ore prospectors exploiting the SaryArkas' copper deposits found in the Zhezkazgan and the Rudny Altai Mountains (Baumer 2016a). A certain parallel is known from the southern area of the Central Asia - the Near East - in term of introduction of metallurgy in the early civilizations of Mesopotamia and India (Roberts et al. 2009). A certain culture-chronological linkage to the ancient Mesopotamia is seen in the Sumerian nation that called themselves Kengirler i.e. Miners (Moorey 1982). The present NE Kazakhstan or Sary-Arka was likely one of the centers of mineral mining and introduction of metallurgy (Chernykh 1992, Baybatsha 1998). The existing archaeological evidence suggest a geographical origin of the Sumerians from somewhere in the Kyrgyz (=Kazakh) steppes on the border between long-headed ancient Indo-Europeans and short-headed Turanians ethnics (Grozny 1940). Altogether, the territory is unique in its material and spiritual culture of the former pastoral traditions spanning over many millennia of occupancy along the historical Silk Road (Barfield 1989). The local geo-settings played a major role in the cultural and economic life of the ancient population of Central Kazakhstan (Margulan et al. 1966). Except for metallic minerals, the broader area of Sary-Arka is also rich of semi-precious and precious stones that attracted attention since the prehistoric times (Pacekov et al. 1990, Sherba et al. 2000, Chernenko and Chlachula 2017).

During the Iron Age ( $1^{\text {st }}$ Millennium BC), northern Kazakhstan was occupied by pastoralist tribes known under the name of Sakas (Saks) 


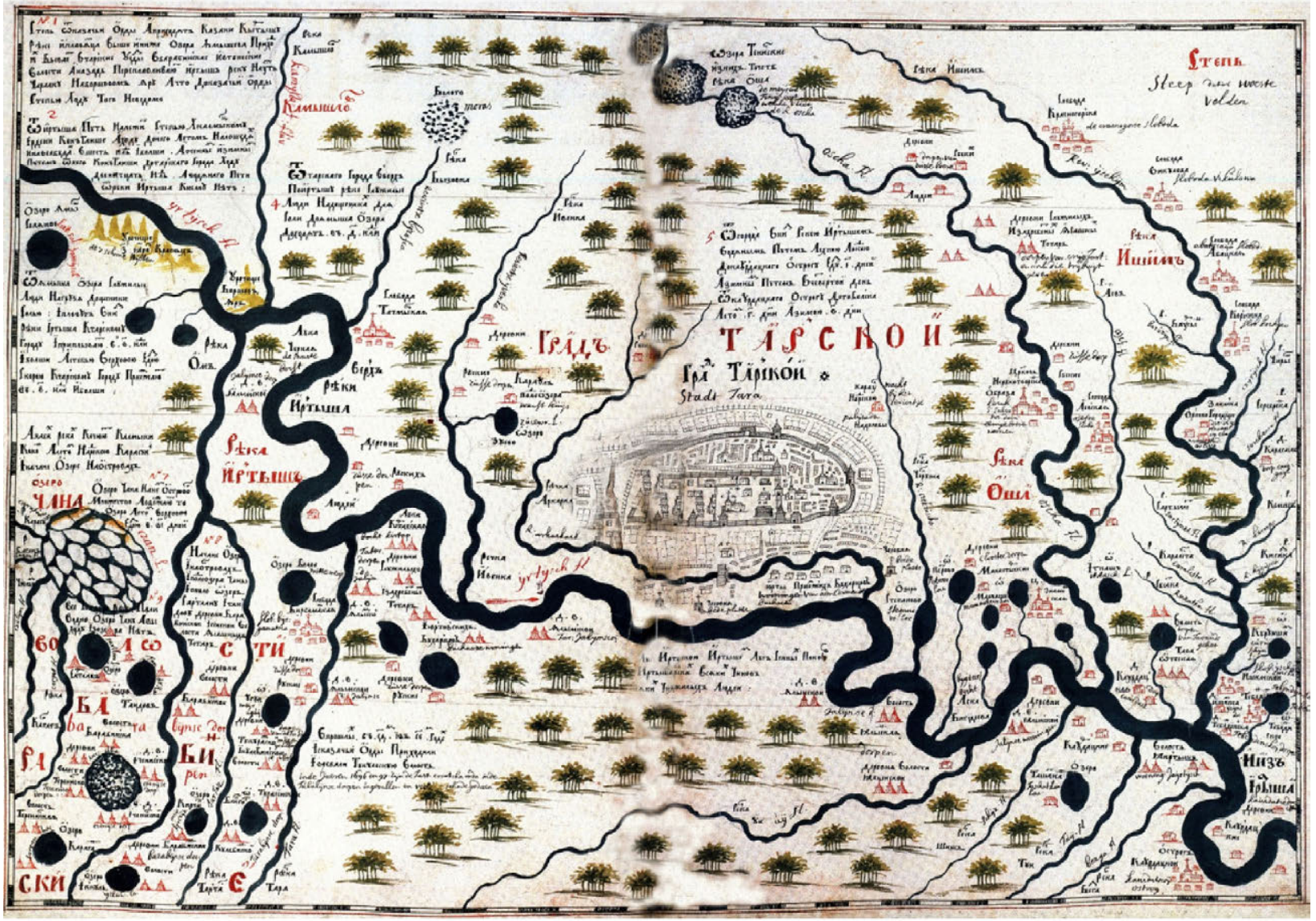

A

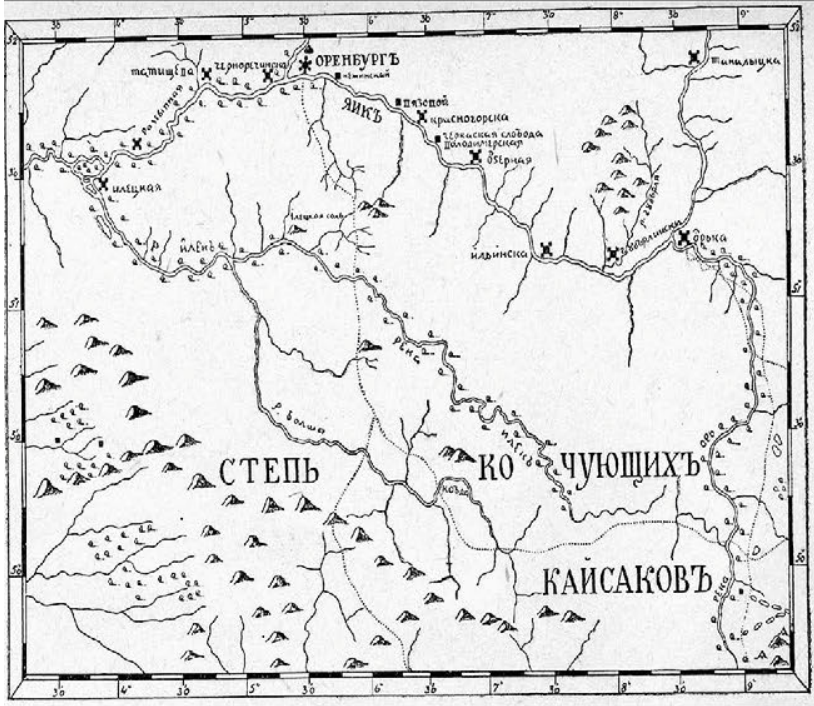

B

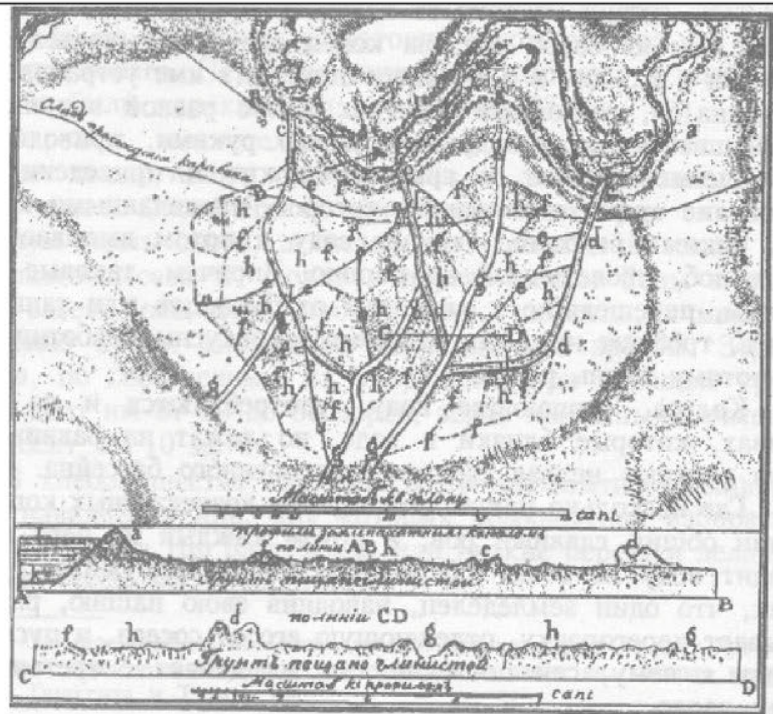

C

Fig. 3. A - The Siberia Sketch cartographic map with geographical loci along the Irtysh River presented by S.U. Remezov (dated to 1697); B - The Kaysakov (Kazakh) nomadic steppe south of the Irtysh/Yertys River; C - A Kyrgyz (Kazakh) steppe-setting plan of arable lands.

mentioned in the old Greek and Assyrian written records as Scythians or Turans. The Arabic and Persian sources refer to the present Central Asia as to the Northern Land or the Tatar Land
- Desht-i-Kipchak of the Batus Ulus - a regional geopolitical entity established by Mongols that absorbed the Turkic tribes of the northern steppes of Central Asia (David 1946). The Turkic-Tatar 


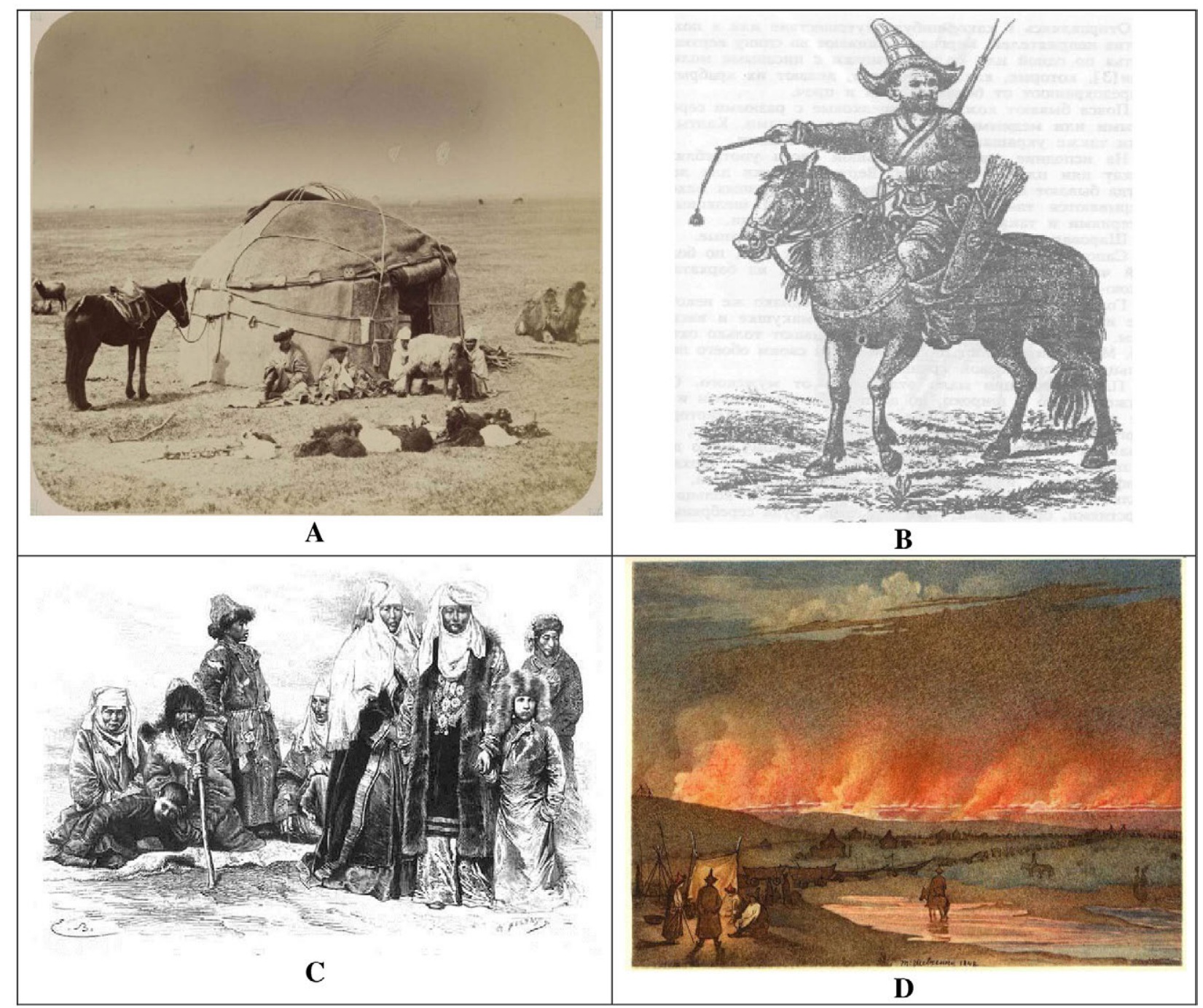

Fig. 4. A - A local pastoralist yurt (kibitka) dwelling of the Kyrgyz (Kazakh) nomads (late 19th century); B illustration of a Kyrgyz horsemen; C - the traditional Kyrgyz (Kazakh) people of the Sary-Arka steppe (19 century); D - fire in the Kyrgyz steppe (a painting by T. Shevchenko, 1848).

ethnic elements became dominant in the following $13^{\text {th }}-15^{\text {th }}$ centuries taking over political powers from the Mongols and consolidated in the Golden Horde fighting with the medieval Russian State. After its political disintegration, independent khanates in the western Siberia and Central Asia were established. From $15^{\text {th }}$ to $18^{\text {th }}$ century, the territory of Sary-Arka became a part of the Kazakh Khanate reaching a major development under Khan/Emir Chagataid Tughlugh Timur (Kundakbayeva 2016). Cattle-breading remained principal economy under the tribal/ extended family social organization. During the $18^{\text {th }}$ until the early $20^{\text {th }}$ century (1925), the territory of the present-day north-central and East Kazakhstan was a part of the Russian Empire (the Tomsk Gubernia) after the collapse of the Kazakh political unity in the $1730-40$ s' $^{\prime}$ and thus a subject of geographic investigations and mapping by the Russian cartographers. Hand-in-hand, the historical linguistic research was carried out in the frame of the Russian geo-political sphere. This is documented by cartographic works and illustrated maps, such as the Sketch of Siberia by Remezov (1697) with the Irtysh River course (Fig. 3), or ethnographic drawings and photographic illustrations depicting the lifestyles and land-use of the local Kyrgyz/Kazakh steppe pastoral people (Fig. 4). In the $19^{\text {th }}$ century, the broader area came into focus of the British Crown in connection with its political interests in Central Asia as documented by the map of Independent Tartary by J.F. Tallis (1851) or the geographic map by A.K. Johnston (1879). 


\section{Method and Approach}

Methodology of the present summarizing study is based on an in-depth analysis of the SaryArka eponymy and toponymy of some principal hydronyms and oronyms providing a culture-historical mosaic of this vast and literally enigmatic steppe-land. Archives of the Gumilov National University, the National Library of the Republic of Kazakhstan and the Archaeological Museum in Astana were used. The place-names' interpretations is based on a multi/proxy approach combining, apart of the linguistic records also ethnological and archaeological evidence and data.

\section{Results: The Sary-Arka Landscape Eponymy}

\section{Oronyms}

Mountains have played a very important role in the life of the ancient inhabitant of SaryArka throughout millennia. The mountain habitats use to provide lush pastures in protected valleys, rich biotopes for hunting-gathering activities as a supplement to the traditional nomadic pastoralism (Chlachula 2011), as well as places of metallic raw material distribution and refuge in times of enemy tribe invasions. Lowto high-elevation mountain systems characterize the topographically broken relief of the present north-eastern and central Kazakhstan, providing witness of intense past regional orogenic processes. Neotectonics is particularly active in the eastern part of the territory with the uplifting Rudno Altai, Southern Altai, Narym, Tarbagatay and Dzungarskiy Alatau ranges (Velikovskaya 1946, Mikhailov 1961, Veselova 1970). Contrary to the orogenically active eastern part of the territory, the geologically mature northern and central part of Sary-Arka constitutes chains of the PreCambrian bedrock structured into systems of separate mountain ranges such as Bayanaul, Ulytau, Shyngystau, Kokshetau, Termirtau, Chingistau, Zhaksy, Karkaly, Kyzylarai, Mugodzhary and some other (Fig. 1) predominantly bearing the old-Turkic or Mongolian names.

The Baitau Mountains toponymy suggests a combination of the Mongolian words bayan, bain - rich and ola, oola - mountain (Konkashpayev
1959). The Kazakhs as the historical population of this area have always called these mountains Bayanaula instead of the Russian form Bayanaul (Fig. 5A-B).The eastern and western geographical extensions of the central Bayanaul massif (Akbet Mt., 1,022 $\mathrm{m}$ a.s.l.) - the Zhaksyaula (Zhaksy) and Zhamanaula, respectively - document the geomorphic diversity with a varying 800-1050 $\mathrm{m}$ altitude range (max. elevation Kyzyltau Mt., 1,055 $\mathrm{m}$ a.s.l.). The modified designation of the Bayanaul Mountains relates to the Russian settlement of the same name - Bayanaul - established in 1826 as a military post in the frontal part of the mountain range. Some similar toponymy variants are also known, such as Bayan-Ola, Bayanaula or Zhaksyaula and Bain-ola meaning rich mountains. Overall, there is a general agreement on the Mongolian linguistic origin of the Bayanaul Mountains. A mountain of a similar name - Bain-ola is located near the present capital of Mongolia, Ulan Bator (Kenesbayev et al. 1971). Another mountain range of Sary-Arka largely formed of granite - the Ulytau Mountains (Kazakh: Ұлытау) located in the southwest of the Kazakh Upland in the NW part of the Karaganda Region (Fig. 5C) indicates the Turkic meaning Great Mountain. This is also one of the oldest mountains ranges (Akmeshit Mt., 1,131 m a.s.l.) in Kazachstan extending ca. 200 km from North to South and geomorphologically characterized by peneplanation surfaces showing intensive past denudation processes and wind-erosion. In the $17^{\text {th }}-18^{\text {th }}$ centuries, the mountains of Argynaty (Ulytau) were considered as the center of the Kazakh steppes and a preferred location of khans the nomadic tribes.

Other mountain ranges of a generally high geological (pre-Cambrian) age are found on the territory of Sary-Arka with a generally Turkic-Kazakh toponymy provenance. The Shyngystau or Chingis-Tau Mountains (Kazakh: Шынгыстау or Чингис-Тау) in the Abay Region of northern Kazakhstan run in a north-west direction at the eastern edge of the vast Central Kazakhstan Uplands - Melkosopochnik (Fig. 1). The central part of the massif forms an undulating plateau of exposed weathered rocky bedrock. Although the principal mountain ranges Akshatau and Kyzylzhal - have the appearance of watersheds, most of the local rivers (Bakanas, Arsalan, Akshatau) emerge at the eastern edge 




Fig. 5. Present landscape physiography associated with the discussed oronyms in north-central and eastern Kazakhstan (Sary-Arka). A. Bayanaul Mountains (700-1,000 m a.s.1.) shaped by Palaeozoic orogenesis with

Lake Zhasybay (Pavlodar Region); B. Bayanaul - the Akbet Mt. (1,022 m) near Lake Toraigyr; C. Ulytau

Mountains (1,133 m a.s.1.) structured of granitic massifs with canyon-shaped planation relief of colorful stratified Mesozoic sedimentary rocks (Ulytau Region); D. Kokshetau Mountains (947 m a.s.l.) with Borovoye/ Buragay (Pine Forest) Lake (Akmola Region); E. Kyzylarai Mountains - Aksoran Mt. (1,565 m), the highest peak of central Kazakhstan (Karaganda Region); F. Mugodzhary Hills (average elevation 400-500 m a.s.1.) formed by the Pre-Cambrian Earth crust uplift and situated in open steppe connecting to the Southern Urals (Aktobe Region). 
of the uplands. The Shyngystau Mountains are bound to the legend of inauguration of Temudzin as of the chief of all the Mongol tribes on one of the mountains' white tops in 1206. Cave Konyr Aulie (Коныр Аулие), a karstic limestone cavity $70 \mathrm{~m}$ long and up to $14 \mathrm{~m}$ high, is traditionally venerated by the Kazakh people in the ChingisKhan's commemoration. A similar geological structure have the Karkaly/Karalaly (Black Stone) Mountains raising in semi-desert north of Lake Balkhash (Fig. 1).

The Kokshetau Mountains in the Akmola Region in northern Kazakhstan are located in the present Burabay National Park. This area is known for natural beauty with lakes surrounded by pine forest, with the principal Lake Borovoye (Fig. 5D). Its name originates from the Russian word bor, which means pine forest; the former Turkic name is Auliekol - holy lake. The Kyzylarai (Kazakh: Кызыларай) Mountains (Aksoran Mt., 1,565 $\mathrm{m}$ a.s.l.) is the highest massive of the Kazakh Uplands located in the Karaganda Region of central Kazakhstan (Fig. 5E). In spite of the barren rocky landscape, numerous prehistoric occupations are associated with this area, including the famous megalithic (Bronze Age) settlement of the Begazy-Dandybaev Culture (Margulan 1979).

The Mugodzhary Mountains (Мугоджарские горы) are considered as the southernmost extension of the Urals massive (Fig. 1) latitudinally running for ca. $200 \mathrm{~km}$ in the form of two parallel ranges - the Western and Eastern Mugodzhary with the highest peak Large Boktybay (657 $\mathrm{m}$ a.s.1.) (Svarichevskaya 1965). The hilly region amid of undulating steppes (Fig. $5 \mathrm{~F}$ ) is drained by several larger rivers, such as Emba and Irgiz, and includes a number of lakes. The broader area of the Southern Urals provided a vital geo-habitat for peopling since the earliest times (Kotov 2016). According to the present understanding, the oronym Mugodzhary or Mugadzhar means sharp top-located ledges. Alternatively it may be linked to the old-Turkic name of the nomadic tribe Mugan occupying this geographically diverse area and the adjoining northern Caucasus during the $10^{\text {th }}-11^{\text {th }}$ centuries AD (Anthony 2006). In the $18^{\text {th }}$ century Russian sources, when this territory was a part of the Empire and under the tsarist jurisdiction, these mountains are mentioned under several names - Mugulzhar-cal, Mugalzharsky, Magulzharskimi or
Mugaldzharskimi Gorami or Magaldir Tau or in as Malgazir in the imperial atlas from 1745 (Tatischev 1950). These names came into general use since the $18^{\text {th }}$ century. If there is some earlier (MiddleAge) etymology linkage to the Mongols (in the Turkic word Mongul or Mogul meaning Mongol or Kalmyk people) remains unclear but cannot be excluded (Menges 1995). The linguistic designation of the local mountains point to their TurkicTartar and more recent Kazakh provenance (e.g., Ala-Bie-Tau - Mottled mountain mare; Dau-Tau - Mountain of dispute; Ken-Kuys/Kenkus - Wide Gorge; Obaly/Ubaly - Burial mound Mountains; Zhaksy Tau - Good Mountain; Jaman-Tau - Poor Mountain).

The highest and most extensive Altai/Altay Mountains include several separate mountain chains adjoining the Southern Altai of East Kazakhstan - the Gorno Altai of southern Siberia, and the Mongolian and Chinese Altai, all with elevations over 4,000 m a.s.l. (Belukha $4503 \mathrm{~m}$ ) (Fig. 6A). Its name comes from the Mongolian Altyn which is translated as gold-bearing or the place where gold occurs or simply the Golden Mountains (Konkashpayev 1959). The word root alt means gold; the suffix tai-place. This interpretation corresponds to the ancient Chinese name of Altai - Jinshan which also means Golden Mountain by referring to the area with abundance of gold (Kenesbayev et al. 1971). Gold as the most precious metal has been mined in this area/since the prehistory (Eneolithic) and particularly during the following Iron Age as witnessed in the World-famous Scythian royal burials found in the local mountain permafrost grounds (Polosmak 2001, Samashev 2010, Chlachula 2018). An alternative explanation of the Altai name is linked with the old Mongolian language as a mountainous country of land rich mountains (Murzaev 1984). The Mongols call the Altai Altaiyn-Nuru. The form Altun yiysh encountered in the Orkhon runic stone inscriptions may then represent an ancient form of the word Altai, which is also based on the word Altun - gold. It cannot be excluded, however, that this name was inherited by the Mongols from ancient times (when the suffix $i$ was still active), and displaced the use of ancient Turkic Altun yiysh. The Mongolian derivation affix ai may corresponds to the Turkic affix $a, a i, i$. Accordingly the name of the Altai clearly bears linkage to both the Turkic and Mongolian 


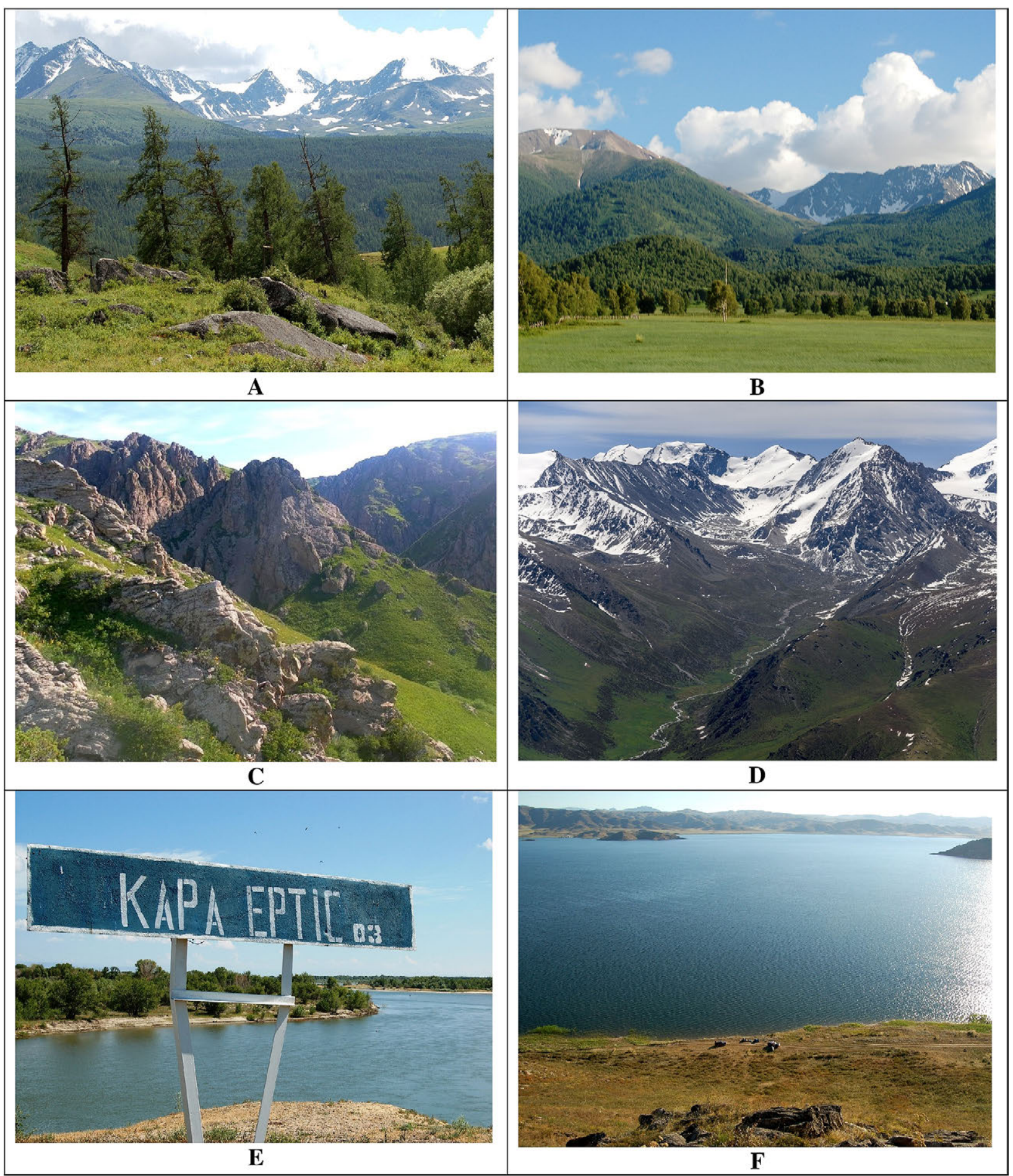

Fig. 6. Present landscape physiography associated with the discussed oronyms and hydronyms in Eastern Kazakhstan. A. Southern Altai massif (4,082 m a.s.1.) (Katon-Karagai District); B. Narym Mountains

(3,816 m a.s.1.); C. Tarbagatai Mountains (2,992 m a.s.l.); D Dzungarskyi Alatau Mountains (4,622 m a.s.1.);

E. Black Irtysh River (Kurchum District) draining from the Chinese Altai; F. Lake Zaisan filling a tectonic depression (water lever at $420 \mathrm{~m}$ a.s.1.) connecting to the Bukhtarma Basin.

languages by combining the two parts: Altun gold - and the derivational affix ai, $i$ meaning golden or gold-bearing (mountains). The etymology of the Narym Range connecting westwards to the
Southern Altai (Fig. 6B) and drained by the river of the same name is believed to be Mongolian.

The identical eponymy root as of the Altai can be seen in the Alatau Mountains (Fig. 6D). 
located further south of the Altai Massive connecting to the Tian-Shan (Fig. 1). Its etymology is evidently associated with the Turkic Alatau meaning motley mountains, i.e., the mountains with a variety of vegetation, rocky landscape and snow caps. According to the early Chinese annals, the name may also refer to a local Alat tribe that belonged to the Hephthalite nation (also called White Huns in the Byzantinian sources) centered in the early Middle Ages $\left(5^{\text {th }}-6^{\text {th }}\right.$ century AD) Baktria (Kurbanov 2010). Equally interesting is the oronym of the mountain range Tarbagatai (2,000-3,000 $\mathrm{m}$ a.s.1.) in eastern Kazakhstan stretching along the border with China (Figs 1, 6C). Its name comes from the Mongolian tarvagan (in the Kazakh tarvaga) - marmot or having marmots by adding the affix tai i.e. the Marmot Mountains (Konkashpayev 1959). This, however, is a certain misinterpretation of the Mongolian tagh-taw-tay meaning mountain by the Turkic nations, such as the Kazakh. All the mentioned oronyms show uniformity in their linguistic formation, with the Turkic affix lyk (Kazakh $l y, d y$ ) and the Mongolian $t u$ also found in a number of other place names of the north-central and eastern Kazakhstan (Bayandin 1949).

In sum, the Sary-Arka landscape and the adjoining mountains of East Kazakhstan are linguistically closely bound to the nomadic ethnics occupying this area for centuries and millennia. A partial ethnic influence and transmission of the place names from one to another is well apparent.

\section{Hydronyms}

The etymology of the north-central and east Kazakhstan hydronyms still does not have an uniform linguistic interpretation in terms of combined linguistic, culture-historical and geographic studies. The main hydronyms of Sary-Arka, i.e., the NE territory of the present Kazakhstan, refer to the principal rivers and their major tributaries. The best example of this is Irtysh- the largest river of Kazakhstan and the area of Sary-Arka.

The Irtysh/Yertys, called the Kara (Black) Irtysh in its upper reaches (Fig. 6E)., starts in the Chinese Altai flowing through the Zaisan Depression and the northern Kazakh stepped prior to joining the $\mathrm{Ob}$ River in the West Siberian Lowland as its main left tributary. Most of the river flows through Kazakhstan, and Russia (about
97\%) and only 3\% through NW China (Fig. 1). Its total length of 4,450 km outreaches the Volga/ Idel River (Slovtsov 1844) the flow rate of which is almost two-times faster than of Irtysh. This denomination reflects the nature of the river itself with Yedel in the old Sarmatian language (Zhedel in Kazakh) meaning fast (Groznyi 1940). Irtysh then is presumably an old Turkic/Tatar name referring as to a Man's mountain (Tatischev 1950). Another interpretation points to the Kalmyk designation of the river as of Irtansh, i.e. the Prince or atheling (Omarov 1975). A total of 1393 rivers drain the present hydrology catchment basin of the Irtysh River, 16 of them are ca. $200-500$ km long

In the ancient Turkic written records in honor of the sultans Kul-Tegin and Tonykok the name of the river Yertys is found exactly with the same pronunciation as in the modern Kazakh language (Abdrakhmanov 1959, Popova 1966) implying a linkage to the homeland of the Kyrgyz-Kazakh nations. By analyzing the etymology of the word Yertys some geographical indices of the river are also encountered in the medieval Hungarian chronicles that mention the Togora River i.e. the same river that is found in the Vienna Illustrated Chronicle by Turots Togata. Among other proposed explanations of the word Irtysh, there is the land and dig of the Kyrgyz language of Irciss found in the old Celtic ethnic dialects subsequently taken over by the Mongols expanding during the $12^{\text {th }}$ and $13^{\text {th }}$ centuries across the northern steppes of Central Asia. Judging from the structure of the word, its second part shesh is likely of the Turkic origin reminding the Kets ses both terms meaning river. The first part may suggest the ancient Indian ar or Arna implying raging stream (Murzaev 1984). This meaning corresponds to hydro-geomorphology of Irtysh being a mountain river in its upper reaches and still representing a swift river with a high water capacity further downstream along its middle courses before transgressing into a major, slow-moving and broadly-meandering channel in the West Siberian Lowland (Popova 1966).

The argumentation for a chronologically relatively recent Mongolian medieval $\left(13^{\text {th }}\right.$ century) origin of the Irtysh name and its dissemination into other eastern languages has support in its linguistic root encountered analogously in the components of other hydronyms of Central Asia 


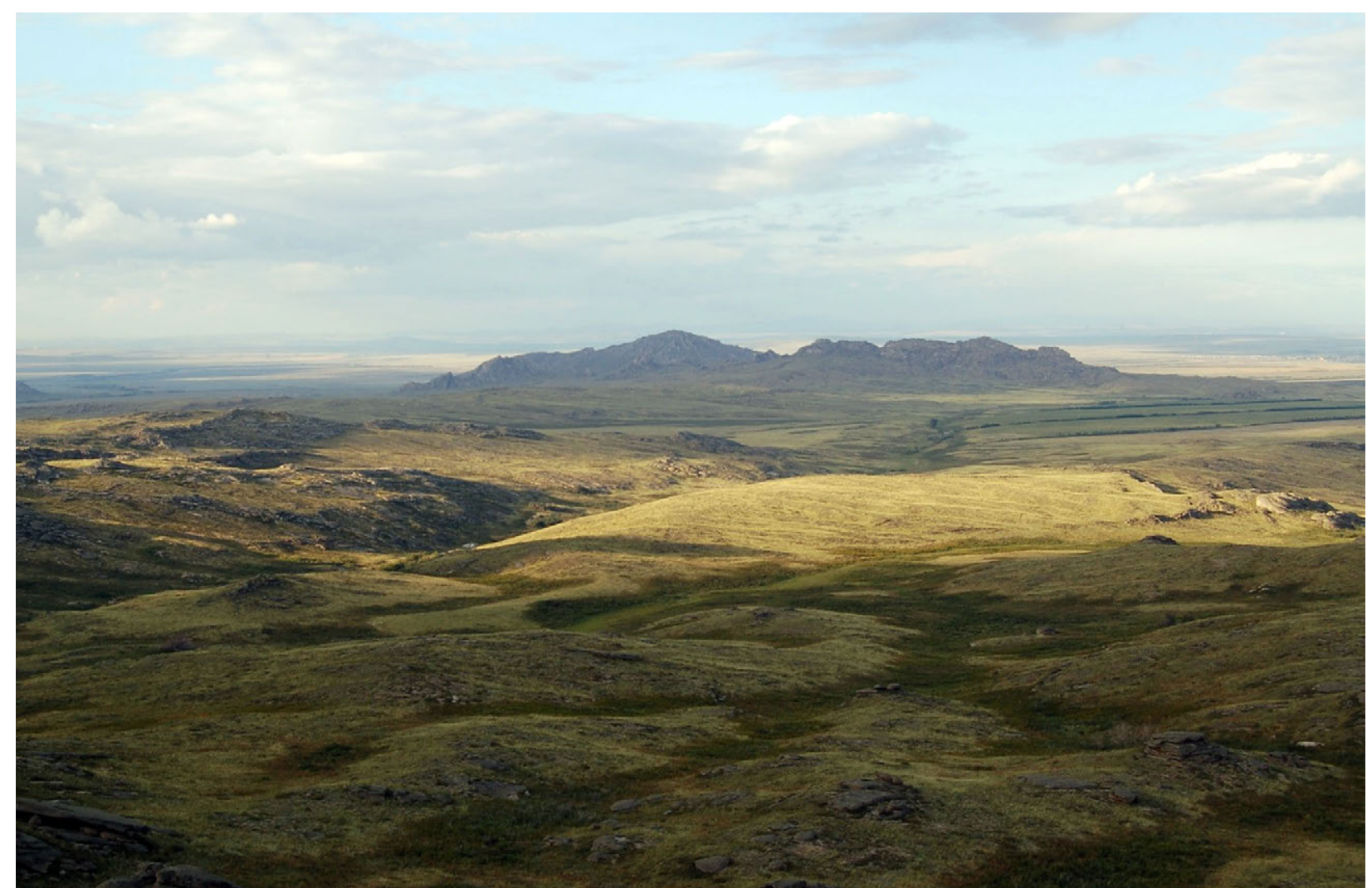

Fig. 7. A geomorphically very diverse semi-arid open steppe landscape of the Sary-Arka (the eastern part of the Central Kazakhstan Highlands - Mel'kosopochnik) with rocky hills and deep ravines formed by exposed PreCambrian granitic bedrock.

-Irsu, Irkol and Irghiz among other (Djanuzakov 1982). The first part of this hydronym - ir - is most likely old Turkic (Sevortyan, 1974). Hydronyms with such a root are also found from Asia Minor to Mongolia (Yrgyz, Irsu, Yrqyt, Yrkel, etc.). The Kazakh irim, Turkish irmak, both meaning river, and the Uzbek irmoq-tributary may all have the same etymology and thus be directly related to the hydronym Ertis. The second component - cis - seems to be associated with the Ket ses providing the final Ir-ses/Irchis/Ircis, i.e. River (Murzaev 1984). Widespread in the south-western Siberia, the originally Iron-Age word ses, shesh (river) was apparently modified in the Turkic language to tish, cis. The first part of the word Ertis - iyir, iyirim, iyirilgen - in the old Turkic language means wandering. Therefore, the combination of the Turkish affix ir and the Ket ses-cis-shesh most likely resulted in the hydronym Ertis and Iyirses eventually turned to Yerses, Yertes. In the present Kazakhstan, there are several geographically broadly distributed place-names formed by the same word component, such as the rivers of Iyiradyr, Iyiri Iyirkel, Iyirsu and some other.
By explaining the Irtysh River eponymy, attention should also be paid to spelling of the word Yertis with the second part meaning water or river. Similar structures have other north-central Asian hydronyms. The Yrghyz (Irgiz) River consists of two components: yrghy - old and su - water, river (Abdrakhmanov 1975). Hence, it is very likely that Iyirty-su (Irty-su) gradually transformed into Iyirtys - Yertys - Irtysh as in the case of the river Yrghy-su, which turned into Yrghyz (Irghiz). Except of the Irtysh River, there is also a lake of a similar name in Bashkiria - Irtash (Irtyash) in the southern Urals. In the Tatar language this means man's stone. Interestingly, the Irtysh as a major river of West Siberia calls in Tatar man's mountain and used to be referred among the local people as to quiet, safe and rich of fish (Slovtsov 1844, Tatischev 1950). The same lake is mentioned by Slovtsov (1844) in his Historical review of Siberia as Lake Irtyash geographically positioned between the Iseti and Miyasa. It should be noted that the Siberian Khanate (also called the Siberian Ulus/Yurt) of the $13^{\text {th }}-15^{\text {th }}$ centuries and encompassing the present territory of NE 
Kazakhstan and western Siberia had close cultural and ethnic links with the southern Trans-Urals and the north Caspian Sea area, where the Nogai Yurt (the Nogai Horde) reigned. The land called Ediger's Siberia laid close to the main Nogai Yurt, and the Siberian Yurt was likely historically located between the Iset and Miyasa Rivers at the Irtyash lake (Kenesbayev et al. 1971). Thus, the Turkic-Tatar linguistic linkage to the Irtysh River is beyond any doubts.

In conclusion, the historical eponymy of the Irtysh River seems to be rather complex. It is likely formed of two linguistic parts of fundamentally different periods - the Celtic ses and the old Turkic Iyir -jointly resulting in the present river's name meaning a meandering or raging river. Finally, it should be taken into account that the Ket ses, shesh has not been preserved in this form in any other language in contrast to Ircis found in Mongolian, Erczis in Chinese and Yertis in Kazakh.

Another principal hydronymy entity of the Sary-Arka concerns the Zaisan Lake (Zaisan Nor, Nor-Zaisan in Kazakh) which is, after Lake Balkhash, the second largest lake of Kazakhstan located in the East Kazakhstan region (Figs 1, 6F). Positioned in the Zaisan tectonic depression, the lake with length of $100 \mathrm{~km}$ and width of $26-39 \mathrm{~km}$ occupies an area of close to $3,000 \mathrm{~km}^{2}$ (Yegorina 2002). According to the present interpretation, the lake's name origin relates to the Mongolian zaasing - noble (Abdrakhmanov 1959, Konkashpayev 1959) and is presumably bound to an old legend. According to this the local people were saved from starvation during the Dzhungar reign by catching local fish which is still rather opulent in the lake waters. In commemoration of this event, the lake was named Zaisan-Nor - Noble Lake (Kenesbayev et al. 1971). In congruence with this explanation, the medieval Mongolian privileged class (nobility) was also called as Zaasing.

\section{Discussion}

As presented above, certain toponyms across the Sary-Arka area have common onomastics background even for the geographically rather distant places. This similarity clearly implies close cultural and economic links, and past political tights also reflected in the ethnological affinities and archaeological records (Gryaznov 1969, Anthony 2002). A certain geographic culture-historical amalgamation over the c. 2,000 km steppe regions from the Altai in the East to the Urals in the West is corroborated by the etymology. A very good example is the name Irtysh. Both the Irtash (Irtyash) Lake in Bashkiria in the southern Urals and the Irtysh (Yertysh) River in NE Kazakhstan have the same linguistic root meaning in the old Turkic language Man's Stone (from ir, er - man and tas, tash - stone or mountain (Tatischev 1950). Another comparative case is the Sibirka River in Bashkiria that drains the Urals foothills as a left tributary of the Chusovaya River, providing evidence of proximity of the Urals Nogai and the West Siberian Yurts (Uluses) - the medieval tribal organizations (Kundakbayeva 2016). This fact points to a broader ethnic uniformity and/or mobility with socio-economic interactions of the ancient populations inhabiting this vast territory.

On the other hand, the linguistic complexity suggests a diversity of the culture-historical origin of the particular ethnics inhabiting the ancient Sary-Arka. Besides of the Irtysh/Yertysh River, no uniform common and scientifically grounded lexical interpretation of other hydronyms is generally accepted. Most of the present place names of the area indicate the Mongolian cultural milieu because of their 150-year presence and reign in the North-Eastern Kazakhstan during the $17^{\text {th }}$ and the early $18^{\text {th }}$ centuries, and previously during the $12-13^{\text {th }}$ centuries. At that time, most of Central Asia was incorporated in the Mongolian Khanate and experienced the allied Tatar invasions (Kundakbayeva 2016). The origin of some place names may go back to the earlier times (the $9^{\text {th }}$ century AD) in association with the Kumak (Kumyk) and Kipchak ethnic substrate (Menges 1995).

A complexity of the ethnic interactions between the north Central Asian groups (Mongolian, Turkic and indigenous, such as Altaic) is also indicated by genetic evidence of the present Kazakh and other Turkic nations' people from the north Kazakhstan-southern Siberia region (Gogkumen et al. 2008). The same pattern of the East-West demographic exchanges and mixing facilitated by the absence of any major physiographic barriers and concretized in the present place names of Sary-Arka can be visualized since the ancient times and represented by the 
proto-Uralic, proto-Altaic and Palaeo-Siberian ethnics (Dolukhanov 2003). The historical toponymy imprint to the Sary-Arka's relief is overwhelmingly Turkic adding to the Mongol place names in the eastern part of the land. The old Turkic influence is linguistically documented across wide areas of Asia from western China and Iran to the Balkans (Sevortyan 1974, Menges 1995, Johanson 2001, Alymov et al. 2010).

Knowledge of the culture-historical evolution, the relief physiognomy formation and anthropogenic-natural interactions to specific geomorphic settings in a particular area contributes to the local landscape management, geoheritage promotion and geotourism development (e.g., Coratza et al. 2012, Migon and Goudie 2012, Thomas 2012, Zwoliński, Stachowiak 2012, Ilieş et al. 2017). The Sary-Arka region of NE Kazakhstan has a major potential in this respect (Zhensikbayeva et al. 2017, 2018).

\section{Conclusion}

The north-central and eastern Kazakhstan (the ancient Sary-Arka) shows a complex and timely long culture-historical evolution reflected in the local place names best-recorded for the major rivers and mountains. Yet, not all the regional eponymy entities can be securely determined using geo-forms' linguistics. In view to the present evidence of the oronyms and hydronyms found on this territory it can be summarized:

- the Turkic affix ly-li, $d y$-di and the Mongolian affix $t u$-ty are of the same linguistic root. These affixes are attached to nouns and form the principal Sary-Arka's place-name background mostly going back to the early Middle Ages;

- the Irtysh River hydronym suggests formation of the river's name by two culturally different linguistic components: the old Turkic iyir wandering and the Ket ses - river, eventually designating the Irtysh River as a meandering or raging river;

- the Mongolian affix tai (e.g. Altai) was created by merging the affixes $t u$ and $a i$;

- an identical cultural (Mongolian) origin can be seen in the East Kazakhstan mountain ranges by adding the affix tai/tau - Tarbagatai, Baitau (Bayantau), Kokshetau, Temirtau and some other mountains.
The toponymy characteristics provide insights into population exchanges in northern Central Asia throughout the millennia since the Eneolithic of the ancient Indo-European inhabitants through the Bronze and Iron Ages ( $3^{\text {rd }}$ and $1^{\text {st }}$ Mill. BC) of the Turanian, Scythian and Saks ethnics until the historical period ( $2^{\text {nd }}$ Mill. AD) represented by nomadic, territorially mobile in part semi-sedentary peoples. The major culture-geographic imprint relates to the Mongolian invasion into the parkland-steppes of the present northern Kazakhstan during the $13^{\text {th }}$ century, and the following Turkic-Tatar tribes politically integrated into the military hordes and representing a substratum of the modern Kazakh nation. Spatial distribution mapping and onomastics understanding of the main geographic entities has a major relevance to the currently expanding (eco-)tourism taking into account all the relief and the associated geo-ecosystem peculiarities and unique nature of the Sary-Arka's territory.

\section{Acknowledgements}

The present study was supported by the L.N. Gumilyov Eurasian National University (Faculty of Natural Sciences). Dr. Irina Chikunova (Institute of Problems of Development of the North, Tyumen Scientific Center, Russian Academy of Sciences) provided useful comments improving the final form of this publication.

\section{References}

Abdrakhmanov A., 1959. The names of the land and water. The Academy of Sciences of the KazSSR, Alma-Ata: 119-120 (in Russian).

Abdrakhmanov A., 1975. Toponymy and Etymology. Nauka, Alma-Ata: 90-93 (in Russian).

Akhmetyev M.A., Dodonov A.E., Sotnikova M.V., 2005. Kazakhstan and Central Asia (Plains and Foothills). In: Velichko, A.A., Nechaev, V.P. (eds), Cenozoic Climatic and Environmental Changes in Russia. Geological Society of America: 139-161.

Alimov R., Tabaldiev K., Belek K., 2010. A newly discovered Turkic inscription in the Tian-Shan region. the CHIYIN TASH rock inscription. Altai Hapko, Biskek.

Anthony D.W., 2006, Three deadly sins in steppe archaeology: culture, migration and Aryans. In: Peterson, D.L., Popova, L.M., Smith, A.T. (eds.), Proceedings of the 2002 University of Chicago Conference on Eurasian Archaeology. Colloquia Pontica 13: 40-62. 
Aubekerov B. Zh., 1993. Stratigraphy and paleogeography of the plain zones of Kazakhstan during the Late Pleistocene and Holocene. Development of Landscape and Climate in Northern Asia in Late Pleistocene and Holocene 1: 101-110. Nauka, Moskva (in Russian).

Aubekerov B., Gorbunov A., 1999. Quaternary permafrost and mountain glaciations in Kazakhstan. Permafrost and Periglacial Processes 10(1): 66-80.

Barfield T., 1989. The Perilous Frontier: Nomadic Empires and China. Cambridge, Mass., B. Blackwell Press, 303 p.

Baumer C., 2016a. The History of Central Asia. Vol. 1: The Age of the Steppe Warriors. I.B. Tauris Press, 372 p.

Baumer C., 2016b. The History of Central Asia. Vol. 2: The Age of the Silk Roads. I.B. Tauris Press, 288p.

Baumer C., 2016c. The History of Central Asia. Vol.3: The Age of Islam and the Mongols. I.B. Tauris Press, 408 p.

Bayandin, N.I., 1949. Some Kazakh geographical names of the Eastern and Central Kazakhstan // Bulletin of the Academy of Sciences of KazSSR 4 (49): 89-90.

Baybatsha A., 1998. The Ancient History of the Kazakh Steppe. Sanat Press, Almaty, 46p. (in Russian).

Baibatsha A.B., Aubekerov B.J., 2003. Quaternary geology of Kazakhstan. Niz Flym, Almaty (in Russian).

Bourgeois I., Mikkelsen H.J., van Hoof L., van Huele W. Bourgeois J., Langohr R., Cammaert L., Decleir H. 2000. An Archaeological Survey of the Kalanegir Valley (Kosh-Agach Region, Altai Republic): Petroglyphs and Scytho-Siberian Kurgans in a Discontinuous Permafrost Area. a Multidisciplinary Approach Ancient Civilizations from Scythia to Siberia 6(1), pp. 77- 101.

Butvilovskiy V.V., 1985. Catastrophic releases of waters of glacial lakes of the south-eastern Altai and their traces in relief. Geomorphology 1985(1), 65-74 (in Russian).

Chernenko Z.I., Chlachula, J., 2017. Precious and decorative non-metallic minerals from East Kazakhstan: geological deposits and present utilisation. Proceedings, $17^{\text {th }}$ International Multidisciplinary Scientific Geoconference SGEM, Sofia-Albena, 29.06.-05.07.2017. 17(11): Science and Technologies in Geology Exploration and Mining, STEF92 Technology Press, Sofia: 447-454.

Chernykh E.N., 1992. Ancient Metallurgy in the USSR. The Early Metal Age. University Press, Cambridge, 339 p.

Chlachula J., 2010. Pleistocene climate change, natural environments and Palaeolithic peopling of East Kazakhstan, in: Chlachula J., Catto, N. (eds), Eurasian Perspectives of Environmental Archaeology. Quaternary International 220: 64-87.

Chlachula J., 2011. Biodiversity and environmental protection of Southern Altai. Studii sicomunicari, Stiintelenaturii 27(1): 171-178.

Chlachula J., 2017. Geomorphology and Geo-Heritage of East Kazakhstan. Abstract Volume, 9 $^{\text {th }}$ Conference on Geomorphology "Geomorphology and Society". Vigyan Bhawan, New Delhi, 6-11 November 2017, Section S: Geomorphosites and Geotourism, Abstract 790: 282.

Chlachula J., 2018. Geo-environmental context of the prehistoric and early historical occupation of the Altai. Archaeological and Anthropological Sciences (submission).

Chupakhin V., 1968. Physical Geography of Kazakhstan. Alma-Ata. "Mektep" Press, 260 p. (in Russian).

Coratza P., Galve J.P., Soldati M., Tonelli C., 2012. Recognition and assessment of sinkholes as geosites: lessons from the island of Gozo (Malta). Questiones Geographicae 31(1), 25-35.
David C., 1946. A History of Russia, Central Asia and Mongolia. Blackwell Publishers, $619 \mathrm{p}$.

Deviatkin E.V., 1965, Cainozoic Deposits and Neotectonics of the South-Eastern Altai, Proceedings GIN AN SSSR, vol. 126, $244 p$. (in Russian).

Deviatkin E.V., 1981, The Cainozoic of the Inner Asia. Nauka, Moskva, 196p (in Russian).

Djanuzakov, T.D., 1982. Essay of Kazakh Onomastics. Nauka, Alma-Ata, 51p. (in Russian).

Dodin A.L., 1961. Principal characteristics of the geological structure and genesis of the eastern part of the Altay-Sayan Structural Zone. In: Nemchinov V.S., Nekrasov N.N., Pustovalov L.V., Zubkov A.I., Gromov LV. (eds), Natural Conditions of the Krasnoyarsk Region. Nauka, Moskva: 99-125 (in Russian).

Dodonov A.E. 2002. Quaternary of Central Asia: Stratigraphy, Correlation, Paleogeography. GEOS, Moskva, 250 p. (In Russian).

Dolukhanov P. 2003. Archaeology and Languages in Prehistoric Northern Eurasia. Japan Review, (15): 175-186.

Dyachkov B.A., Mayorova N.P., Chernenko Z.I., 2014. History of East Kazakhstan geological structures development in the Hercynian, Cimmerian and Alpine cycles of tectonic genesis, Part II. Proceedings of the Ust-Kamenogorsk Kazakh Geographical Society, D.Serikbaev East Kazakhstan State Technical University Press, Ust-Kamenogorsk: 4248 (in Russian).

Erofeev V.S., 1969. Geological History of the Southern Peripheries of the Altai in Paleogene and Neogene. Academy of Science of the Kazakh SSR, Alma-Ata, 166p (in Russian).

Frachetti M.D., 2006. The Dhzungar Mountains archaeology project. reconstructing Bronze Age life in the mountains of East Kazakhstan. In: Peterson D.L., Popova L.M., Smith, A.T. (eds), Proceedings of the 2002 University of Chicago Conference on Eurasian Archaeology Colloquia Pontica 13: 122-141.

Galakhov V.P., Mukhametov P.M., 1999. Glaciers of the Altai. Nauka, Novosibirsk, 136 p.

Geta R.I., Yegorina A.V., Saparov K.T., Zhensikbaeva N.Z., 2015. Methods for Assessing the Recreational Potential of the Kazakhstan Part of Altai on the Basis of Information Theory, In: Academy of Natural Sciences. International Journal of Experimental Education, Moscow: 10-14.

Goessling S., Hall C.M., 2005.Tourism and Global Environmental Change. Ecological, Social, economic and political interrelationships. Routledge Publishers, London-New York, 331 p-

Gokcumen O., Dulik M. C., Pai A.A., Zhadanov S.I., Rubinstein S., Osipova L.P., Andreenkov O.V., Tabikhanova L.E., Gubina M.A., Labuda D., Schurr T.G., 2008. Genetic variation in the enigmatic Altaian Kazakhs of South-Central Russia: Insights into Turkic population history. American Journal of Physical Anthropology 136: 278-293.

Gorbunov A., Samashev Z, Severskiy E., 2005. Treasures of Frozen Kurgans of the Kazakh Altai. Materials of the Berel' Burial Ground. Il'-Tech-Kitap, 114 p (in Russian).

Grigoriev V.V. (ed.), 1950. Kazakhstan, General Physiogeographic Characteristics. Nauka, Leningrad, $492 \mathrm{p}$ (in Russian).

Groznyi B., 1940. Prehistoric Age of Asia Minor. $2^{\text {nd }}$ Edition. Vladivostok, 44 p. (in Russian).

Gryaznov M.P., 1969. The Ancient Civilisations of Southern Siberia. Nagel Publisher, Geneva, 251p. 
Herget J. 2005. Reconstruction of Pleistocene ice-dammed lake outburst floods in Altai- Mountains, Siberia. Geological Society of America, Special Publication, $386 \mathrm{p}$

Ilieş M., Ilieş G., Hotea M., Wendt J.A., 2017. Geomorphic attributes involved in sustainable ecosystem management scenario for the Ignis-Gutai Mountains Romania. Journal of Environmental Biology 38(5): 1121-1127.

Johanson L., 2001. Discoveries on the Old Turkic Linguistic Map. Swedish Research Institute, Uppsala, 56p.

Johnston A.K., 1879. A map of Central Asia. Scale: 1:4979779. David Rumsey Historical Map Collection.

Kenesbayev S.K, Abdrakhmanov A.A., Donidze G.I., 1971. Place Names of Kazakhstan, their research, writing and transcription. Proceedings of the Academy of Sciences of the KazSSR. Public Series 4: 73-74.

Khazanov A.M., 1984. Nomads and the Outside World. Unly of Wisconsin Press, 256 p.

Konkashpaev G.K., 1959. Geographical names of Mongolian origin in Kazakhstan. Proceedings of the Academy of Sciences of the KazSSR. Philology and Art History Series 1(11): 91 (in Russian)

Konkashpayev G.K., 1959. Kazakh folk geographical terms. Proceedings of the Academy of Sciences of the KazSSR. Geographical Series 3: 7. (in Russian).

Kotov V.G., 2016. The cave Sanctuary Shulgan-Tash (Kapova): structure, traces of rituals, semantics of images. In: Khisamitdinova, F.G., Kotov, V.G., Nafikov, Sh..V. (eds), Ancient Sanctuaries: Archaeology, Ritual, Mythology. The Burziyan District of the Republic of Bashkortoskan. Proceedings, International Symposium, 17-20. June 2015, Institute of History, Ufa: 41-63.

Kozhamkulova A.A., Kostenko N.N., 1984. Extinct Animals of Kazakhstan. (Palaeogeography of Late Cainozoic). Nauka, Alma-Ata, 104 p. (in Russian).

Kundakbayeva Z., 2016. The History of Kazakhstan from the Earliest Period to the Present time. Volume 1 Kazak University Press, Almaty.

Kungurov A.L., 2006. History of investigations of the stone age of Rudnyy Altay. In: Eastern Studies in the Altay (Vostokovedenie na Altae), Altay State University, Barnaul, 4: 4-12 (in Russian).

Kurbanov A., 2010. Hephthalites. PhD. Dissertation, Freie Universitat Berlin, Berlin, $300 \mathrm{p}$.

Levine M., Kislenko A., 1997. New Eneolithic and Early Bronze Age Radiocarbon Dates for North Kazakhstan and South Siberia. Cambridge Archaeological Journal 7(2): 297-300.

Margulan A.Kh., 1979. Begazy-Dandybaev Culture of Central Kazakhstan, Nauka, Alma-Ata (in Russian).

Margulan A., Akishev K., Kadybaev M., Orazbaev A., 1966. Ancient culture of Central Kazakhstan. Nauka, Alma-Ata, 5 p. (in Russian).

Mazbaev O.B., 2016. Geographical Bases of Territorial Development of Tourism in Republic of Kazakhstan, Ph. D. Thesis, Al-Farabi Kazakh National University, Almaty, 138 p (in Russian).

Medoyev G.Z., 1948. Sary-Arka - reflections to toponymy of Kazakhstan. Bulletin of the Academy of Sciences of the KazSSR 1(34): 20-54. (in Russian).

Menges K.H., 1995. The Turkic Languages and People. An Introduction to Turkic Studies. Veroeffentlichungen der Societas Uralo-Altaica, Vol. 42. Harrassowitz Verlag, Wiesbaden, $253 p$.
Migon P., Goudie A., 2012. Pre-Quaternary geomorphological history and geoheritage in Britain. Questiones Geographicae 31(1), 67-79.

Mikhailov N.I., 1961. Mountains of Southern Siberia. Nauka, Moskva (in Russian).

Mikhailova N.I., 2002. Environmental Evolution of East Kazakhstan in Cainozoic Period. In: Regional Components in System of Ecological Education, Ust-Kamenogorsk: 88-93 (in Russian).

Motuzaite Matuzeviciute G., Lighfoot E., Connell T.C.O., Vyvakin D., Liu X., Loman V., Svyatko S., Usmanov E., Jones M.K., 2015. The extent of cereal cultivation among the Bronze Age to Turkic period societies of Kazakhstan determined using stable isotope analysis of bone collagen. Journal of Archaeological Science 59: 23-34.

Mooray P.R.S., 1982. The archaeological evidence for metallurgy and related technologies in Mesopotamia, c. 5500.2100 B.C. Iraque 44(1). 13-38.

Murzaev E.M., 1984. Dictionary of National Geographical Terms. Nauka, Moskva, 55 p. (in Russian).

Nekhoroshev V.P., 1958. Geology of the Altay. Moskva, Gosgeoltekhizdat, $262 \mathrm{p}$ (in Russian).

Nekhoroshev V.P., 1967. Eastern Kazakhstan. Geological Structure, In: Sidorenko A.V., Nedra M. (eds.), Geology of the USSR, Volume 41, Nauka, Moskva-Leningrad, 467 p. (in Russian).

Nobis M., Gudkova P. 2016. Taxonomic notes on feather grasses (Poaceae: Stipa) from eastern Kazakhstan with typification of seven names and one new combination. Phytotaxa 245(1): 31-42.

Obruchev V.A., 1951. Selected Works on Geography of Asia. Volume 2, Geografizdat, Moskva, 400 p. (in Russian).

Omarov T.R., 1975. Rivers and lakes of Kazakhstan. Nauka, Alma-Ata: 58-59 (in Russian).

Outram A.K., Stear N.A., Bendrey R., Olsen S., Kasparov A., Zaibert V., Thorpe N., Evershed R.P., 2009. The earliest horse harnessing and milking. Science 323 (5919): 13321335.

Pacekov U.M., Jukova A.A., Alekseyev A.G., Artemeva E.L., 1990. Minerals of Kazakhstan, IGS AS KazSSR, Alma Ata, 196 p. (in Russian).

Plit J., Myga-Piątek M., 2014, The degree of landscape openness as a manifestation of cultural metamorphose. Questiones Geographicae 33(3): 145-154.

Polosmak N.V., 2001. Inhabitants of Ukok. Infolio, Novosibirsk, 334 p (in Russian).

Popova V.N., 1966. On some hydronyms of the Pavlodar area. In: Languages and Toponymy of Siberia. Tomsk University Press, Tomsk: 17-24 (in Russian).

Postgate J.N., 1993. Early Mesopotamia. Society and Economy at the Dawn of History. Routledge, London and New York, $366 \mathrm{p}$.

Roberts B.W., Thornton H.P., Pigott W.C., 2009. Development of Metallurgy in Eurasia. Antiquity 83(322): 10121022.

Rudoy A.N., Baker V.R., 1993. Sedimentary effects of cataclysmic late Pleistocene glaciál outburst flooding, Altay Mountains, Siberia. Sedimentary Geology 85: 53-62.

Rudoy A.N., Kirianova M.R., 1994. Lacustrine and glacial lake formation and Quaternary paleogeography of the Altay. Proceedings of the Russian Geographical Society 121(3): 236-244 (in Russian).

Samashev Z., 2001. Archaeological Monuments of the Kazakh Altai. Institute of Archaeology, Almaty, 108 p (in Russian). 
Samashev Z., 2011. Berel'. Ministry of Education and Science, Archaeological Institute, Taimas Press, Astana, 236 p.

Saparov K.,T., Zhensikbayeva N., Z., 2016. Evaluation of the Natural Resource Potential of the Southern Altai, Vestnik, D. Serikbayev East Kazakhstan State Technical University Scientific Journal, Ust-Kamenogorsk: 66-71.

Schulz S.S., 1948. Analysis of Neotectonics and Relief of the Tian-Shan. Proceedings of the Soviet Geographical Society, Vol. 1, Nauka, Moskva-Leningrad, 201 p. (in Russian).

Sevortyan, E.V., 1974. Etymological Dictionary of the Turkic Languages. Volume 1. Nauka, Moscow, 174 p. (in Russian).

Sherba G.N., Bespayev X.A., Dyachkov B.A., 2000. Large Altai (Geology and Metallogeny). RIO VAC RK, Almaty, 400p. (in Russian).

Slovtsov P.A., 1844. Historical Review of Siberia. Book 2 (From 1742 to 1823). St. Petersburg: Typography Karl Krai Press, 149 p. (in Russian).

Svarichevskaya I., 1965. Geomorphology of Kazakhstan and Central Asia. Nauka, Leningrad (in Russian).

Tallis J.F., 1851. A map of Independent Tartary. Scale: 1:10600000 David Rumsey Historical Map Collection.

Tatischev V.N., 1950. Selected Works on Geography of Russia. Nauka, Moskva, 180p. (in Russian).

Thomas M.F., 2012. A geomorphological approach to geodiversity - its applications to geoconservation and geotourism. Quaestiones Geographicae 31(1): 81-89.

Van der Heide N.. 2015. Spiritual Performance. The Manas Epic and Society of Kyrgyzstan. Rozenberg Series 3, Academic Press, GmbH, Bremen, 350p.

Velikovskaya E.M., 1946. Relief Development of the Southern Altai and Kalba and Deep Gold Placete. Bulletin of the Moscow Institute of Petrology, Geology Section, 21(6): 57-77 (in Russian).

Veselova L.K., 1970. Morphostructure of the South-Eastern Kazakhstan Mountains. In: Geography of Desertic and Mountain Region of Kazakhstan, Nauka, Moskva-Leningrad, pp. 38-48 (in Russian).

Vishnyatsky L.B., 1999. The Paleolithic of Central Asia. Journal of World Prehistory 13(1): 69-122.

Yegorina A.V., 2002. Physical Geography of East Kazakhstan, Ust-Kamenogorsk, EHI publishing house, $181 \mathrm{p}$.

Yegorina A.,Saparov K. T., Zhensikbayeva N.Z., 2016. The Structure of the Geo-Cultural Space of Southern Altai as a Factor of Tourist-Recreational Development, Vestnik KNU, Scientific Journal. Almaty: 214-219.

Zakh V.A., Ryabogina N.E., Chlachula J., 2010. Environmental dynamics of the Holocene occupation of the Tobol-Ishim region, West Siberia. In Eurasian Perspectives of Environmental Archaeology (J.Chlachula and N.Catto, Editors). Quaternary International 220: 95-101.

Zhensikbayeva N., Saparov K.., Atasoy E., Kulzhanova S., Wendt J., 2017. Determination of Southern Altai geography propitiousness extent for tourism development, in: GeoJournal of Tourism and Geosites 9(2): 158-164.

Zhensikbayeva N.Z., Saparov K.T., Chlachula J., Yegorina A.V., Atasoy A., Wendt J.A., 2018. Natural potential of tourism development in southern Altai. GeoJournal of Tourism and Geosites IX/1 (21): 200-212.

Zwoliński Zb., Stachowiak J., 2012. Geodiversity map of the Tatra National Park for geotourism. Quaestiones Geographicae 31(1): 99-107. 